Editorship of Discovery : Mr. S. E. Gamarekian

s. Edward Gamarekian has been appointed editor of Discovery. He carried out research and development work at the General Flectric Company's Laboratories in Schenectady, New York, for many years and lectured at Rutgers University, Rensselaer Polytechnic Institute and the Georgian Institute of Technology. He later became the scientific correspondent for The Washington Post and recently came to Britain to report on scientific developments for The Guardian during a three-month exchange of science correspondents between the two newspapers.

\section{Recovery of Capsules from Discoverer Satellites}

THE first success in retrieving an object which had returned to Earth after boing in orbit in space was achieved on August 12, when the re-entry capsule from the United States satellite Discoverer 13 was recovered from the North Pacific. Discoverer 13 $(1960 \theta)$ was launched from Vandenberg Air Force Base, California, at 20h. 40m. U.r. on August 10, and entered an orbit inclinod at $83^{\circ}$ to the equator. Its height varied between $260 \mathrm{~km}$. at perigee and $700 \mathrm{~km}$. at apogee, the orbital period being $94 \cdot 1 \mathrm{~min}$. Seventeen revolutions later, the re-entry capsule was detached from the main body of the satellite when it was travelling south near the Aleutian Islands, and, after its speed had been substantially reduced by a retro-rocket, it descended through the atmosphere. In the last fow miles of its descent it was further retarded by parachute and was finally recovered from the sea north of Hawaii. It was found to have withstood woll the heating encountered during its descent. On August 19 there was successful recovery of a second capsule, ejected from the satellite Discoverer $14(1960 x)$, which was launched at $19 \mathrm{~h}$. $58 \mathrm{~m}$. U.'. on August 18 into an orbit similar to that of its prodecessor. On this occasion the capsule, which weighed $85 \mathrm{lb}$., was intercepted during its final parachute descent, being caught by an aircraft at an altitude of about $10,000 \mathrm{ft}$. over the north Pacific.

\section{The Satellite Echo I (1960 ¿)}

The first successful balloon-satcllite was launched from Cape Canaveral in Florida at $09 \mathrm{~h} .40 \mathrm{~m}$. U.T. on August 12. The satellite, known as Echo 1, consists of an aluminium-coated plastic sphere $100 \mathrm{ft}$. in diameter, which was inflated at high altitude. Its orbit is inclined at $47^{\circ}$ to the equator, with a period of revolution of $118.2 \mathrm{~min}$. initially. The orbit is nearly circular, the height being $1,530 \mathrm{~km}$. at perigee and $1,690 \mathrm{~km}$. at apogee. The satellite, which is designated 1960 ` 1 , is accompanied in orbit by its final-stage rocket $(1960 \iota 2)$, and three other fragments. The main purpose of the satellite is to act as a reflector for radio waves, and many transmissions have been successfully received via the satellite. It thus serves as a first step towards a world-wide communications system which would be independent of ionospheric disturbances. The satellite is also admirable for optical tracking, and during its first week in orbit was easily visible from most of the northern hemisphere, as a slow-moving object of stellar magnitude zoro. The satellite should also yield the first information on air density at heights above 1,000 km., and evidence of its behaviour under the impact of metcorites is awaited with interest.

\section{Australia's Second Atomic Reactor}

Austranda's second atomic reactor is to be called by the aboriginal name of Moata. This is the first in the world to bear a tribal name. The name Moata is used by the Ngerikudi tribe in Northern Qucensland to describe instruments for making heat or 'nativo firesticks'. Moata, an Argonaut type of experimental reactor, is now under construction at the Advanced Technology Laboratories at Mountain View, California, and will be installed at Lucas Heights early noxt year.

\section{Information Centre for Food Irradiation}

As international information centre for food irradiation has been set up as a result of a contract signed between the European Productivity Agency of the Organization for European Economic Cooporation and the Centre d'Etudes Nucléaires at Saclay, France. M. Picrre Lévèque has been appointed director of the Centre, which will be sot up at Saclay. The functions of the Centre include the preparation, publication and distribution of a quarterly international newsletter on food irradiation in both Fnglish and French. The Centre will also serve as a point of contact between scientists, food technologists and the government and industrial circles interested, and will encourage closer international cooperation in the development and application of knowledge in the field of food irradiation. The contract, which has been signed for an initial period of two years, provides for the payment by the sponsoring bodies of a sum of 32,000 new francs to cover printing and translation costs and other incidental expenses of the Centre. It is hoped that the work of the European Information Centre for Food Irradiation will encourage investigation and research and promote the successful industrialization of the results obtained.

\section{Bibliographies on Technical and Vocational Educa- tion}

A SERrEs of bibliographies on technical and vocational education has been launched by Unesco. Besides an international bibliography, surveys have been published giving details of publications in the United Kingdom and in the U.S.S.R. concorned with the technical and vocational aspects of education. To these is now added a bibliography of technical oducation publications in the United States (Educational Studics and Documents No. 36 : Technical and Vocational Education in tho U.S.A.-a Bibliographi. cal Survey prepared by the United Statos Office of Education. Pp. 24. (Paris: Unesco ; Iondon : H.M. Stationery Office, 1959.) 3s. 6d.) The booklet is in five parts and lists separately publications dealing with general technical and vocational edueation, agriculture, distribution, home economics and industrial education; there is an explanatory note to cover each publication described, stating briefly its contents and purpose.

\section{Low-priced Books for Overseas}

SINCE this scheme was first started, some 2,000 titles have been submitted by publishers and others to the Advisory Committee on the Selection of Low priced Books for Overseas under the chairmanship of Mr. A. L. P. Norrington, president of Trinity College, Oxford, and vice-chancellor (designate) of the University. The Committee will shortly be submitting its list of recommendations to the Ministers concerned. Some measure of priority is being given to university text-books, as the importance attached to the supply of books of educational, scientific and technical value was clearly brought out at the 